\title{
ANALYSIS OF FACTORS INFLUENCING THE PRODUCTIVITY OF LOWLAND RICE DURING THE SECOND PLANTING SEASON IN PALEMBANG CITY, INDONESIA
}

\author{
Septiana Betaria, Yazid Muhammad*, Hakim Maryati Mustofa \\ Master Program in Agribusiness, Faculty of Agriculture, University of Sriwijaya, Indonesia \\ *E-mail: yazid ppmal@yahoo.com
}

\begin{abstract}
Swamp rice cultivation during the second planting season (October-March), known as IP 200, which is directed in 4 sub-districts in Palembang is expected to contribute to rice production for the city of Palembang and to support national food security program. Out of 4 sub-districts, 3 sub-districts were chosen to be the locations of this survey. Respondents of this survey were members of the farmer groups who were selected randomly using proportionate random sampling. The results showed that lowland rice production in the second planting season was influenced significantly by farmers' technical ability in cultivation $\left(X_{1}\right)$, production facilities and infrastructure $\left(X_{2}\right)$ and irrigation networks $\left(X_{3}\right)$.
\end{abstract}

\section{KEY WORDS}

Swamp rice, planting, food program, food security.

Agriculture development is an integral part of national development in Indonesia and its role has become a solid foundation for the nation's economy. Agricultural sector has contributed to the achievement of the nation's food security. The efforts of food security achievement are mostly focused on increasing food self sufficiency, especially rice (Agus and Irawan, 2006). However, currently land use conversion has become a major threat to agricultural development and food security (Long et al., 2009 in Sulaeman, 2016).

The Directorate General of Food Crops (2013) explained that one alternative to overcome the impact of conversion of agricultural land is to optimize the use of potential agricultural land. One of the strategies is to expand the planting areas by utilizing potential lands such as upland, lowlands and tidal swamp lands and the implementation of multiple cropping.

To respond to the national programs and policies and to support the Province of South Sumatra in strengthening the capacity of the region to be self-sufficient in food supply, the city of Palembang also played a role through the optimization of its agricultural sector. Based on the data from the Central Bureau of Statistics of Palembang (2016), it still has potential agricultural land of 11,526 ha, consisting of dry land and non-irrigated rice fields which are categorized as swamp areas. The potential of swamp land suitable for rice cultivation was 6,028 hectares, among which 5,734 hectares had been used by farmers for rice farming with one planting season per year (April - September). Therefore, the Government of Palembang since 2015 began to implement rice cultivation in the second planting season (October March) with the target stated in Table 1.

Table 1 - Lowland rice cultivation in the second planting season in Palembang in 2015-2017

\begin{tabular}{llll}
\hline \multicolumn{1}{c}{$\mathrm{n} / \mathrm{n}$} & 2015 & 2016 & 2017 \\
\hline Target of Planting (Hectares) & 500 & 500 & 500 \\
Realization of Planting (Hectares) & 254 & 407 & 294 \\
Harvest Area (Hectares) & 208 & 407 & 294 \\
Productivity (Tons/Hectare) & 4,69 & 6,15 & 6,713 \\
Production (Ton) & 975,52 & 2503,05 & 1.974 \\
\hline
\end{tabular}

Since 2015, rice cultivation in the second planting season (October-March) known as IP200, has been implemented in 4 districts, namely Gandus, Kertapati, Kalidoni, and 
Sematang Borang in 6 sub-districts. The target area was 500 hectares, involving 355 farmers.

Table 2 - The target of lowland rice cultivation in the second planting season in Palembang

\begin{tabular}{ccccc}
\hline District & Sub-District & Farmers' Group & $\begin{array}{c}\text { Area } \\
\text { (Hectares) }\end{array}$ & Number of Farmers \\
\hline \multirow{2}{*}{ Gandus } & \multirow{2}{*}{ Pulokerto } & Gapoktan Bina Usaha Mandiri & 50 & 41 \\
& & Gapoktan Seberang Ulu & 150 & 90 \\
& Kelompoktani Mandiri & 50 & 25 \\
\hline \multirow{2}{*}{ Kertapati } & Karya Jaya & Gapoktan Karya Makmur & 100 & 95 \\
& Keramasan & Kelompoktani Suka Karya & 50 & 25 \\
\hline \multirow{2}{*}{ Kalidoni } & Sei Selincah & Gapoktan Petani Bersatu & 50 & 20 \\
\hline \multicolumn{6}{c}{ Kematang Borang } & Karya Mulia & Kelompotani Karya M.Mulia & 30 & 40 \\
& Suka Mulia & Kelompoktani Cahaya & 20 & 19 \\
\hline
\end{tabular}

In order to support rice production enhancement through the implementation of lowland rice cultivation in the second planting season (October-March), several factors are considered to influence the successful of the program, namely 1) the ability of farmers to implement lowland rice cultivation, 2) the availability of production facilities (seeds, fertilizers, pesticides) and agricultural machinery, and 3) the condition of irrigation networks that affect water conditions in the planting area. Therefore, this research was conducted to find out factors that influence the implementation of lowland rice cultivation in the second planting season (October-March) in Palembang.

\section{METHODS OF RESEARCH}

This research was conducted in three districts where lowland rice cultivation was implemented in the second planting season, namely Kalidoni, Sematang Borang, and Kertapati from September to October in 2018. This research employed survey method. The population of this research was farmers in the 3 districts who conducted rice cultivation in the second planting season. The population was as many as 199 farmers. Sample farmers were drawn from the population using proportionate random sampling. Total numbers of sample farmers were 40 farmers.

Data collected in this research consisted of primary and secondary data. Primary data were collected through direct interviews to the respondents using a questionnaire. Secondary data were collected from papers, reports, and publications related to this research. Data collected were tabulated and descriptively analyzed. Meanwhile, to analyze the factors that influenced the production of lowland rice cultivated in the second planting season, the following equation is employed:

$$
Y=a+b_{1} X_{1}+b_{2} X_{2}+b_{3} X_{3}
$$

Where: $Y=$ Productivity of rice in the second planting season; $\alpha=$ Constant; $\beta=$ Regression coefficient; $X_{1}=$ Farmers' technical ability to perform rice cultivation; $X_{2}=$ Production facilities and infrastructure (seeds, fertilizer, pesticides, machinery); $X_{3}=$ Irrigation networks.

Furthermore, to find out whether the three variables $\left(X_{1}, X_{2}, X_{3}\right)$ have a significant effect on the dependent variable $(Y)$, a partial test ( $t$ test) was carried out. In addition, to test the overall effect of the independent variables on the dependent variables, a simultaneous test $F$ test) was used.

\section{RESULTS AND DISCUSSION}

The Development of Rice Cultivation in the Second Planting Season. Rice cultivation in second planting season in three districts in Palembang has been implemented since 2015. Table 1 described the target and realization of planting, harvest area, and productivity in 
three districts in 3 consecutive years since 2015. There was a variation of target and realization in planting in District Kalidoni, but there was an increase in District Sematang Borang and Kertapati. However, in all district the productivity increased significantly from 2015 to 2017.

Table 3 - Lowland rice cultivation in the second planting season in 2015-2017

\begin{tabular}{cccccccccc}
\hline $\mathrm{n} / \mathrm{n}$ & \multicolumn{3}{c}{ Kalidoni } & \multicolumn{3}{c}{ Sematang Borang } & \multicolumn{3}{c}{ Kertapati } \\
& 2015 & 2016 & 2017 & 2015 & 2016 & 2017 & 2015 & 2016 & 2017 \\
\hline Target of Planting (Hectares) & 50 & 250 & 150 & 50 & 75 & 90 & 150 & 50 & 150 \\
\hline Realization Planting (Hectares) & 115 & 372 & 130 & 90 & 45 & 66 & 28 & 0 & 100 \\
\hline Harvest Area (Hectares) & 115 & 372 & 128 & 80 & 30 & 66 & 3 & 0 & 100 \\
\hline Productivity (Tons/Hectare) & 5.1 & 6.25 & 6.2 & 5.05 & 6.05 & 7.04 & 4.4 & 0 & 6.9 \\
\hline Production (Ton) & 586.5 & 2,325 & 793.6 & 404 & 181.5 & 464.6 & 13.2 & 0 & 690 \\
\hline
\end{tabular}

In 2015, there were 2 districts (Kalidoni and Sematang Borang) whose realization of the harvest area was above the target. Whereas District Kertapati was much below the target which only achieved 3 ha out of 150 ha targeted. In 2016, rice cultivation in the second planting season in the two districts was targeted higher than that in 2015, but District Kertapati was targeted lower due to the harvest fail in 2015. The area harvested in 2016 in District Kalidoni was achieved, but in District Sematang Borang the harvest area was lower than the target. Even, in District Kertapati there was no realization in planting in 2016. In 2017, in all three districts rice cultivation in the second planting season were re-targeted. Table 3 showed that in 2017 in all three districts, the targeted harvest area was achieved.

Overall, Table 3 revealed that the realization of rice cultivation in the second planting season (October-March) in 2015 was 254 hectares with the harvest area of 208 ha and the average productivity of 4.69 tons of dry harvest grain (GKP) per hectare. Furthermore, in 2016, the realization of both harvest area and productivity were higher than the previous year. The harvest area has increased to 407 hectares and the productivity has increased to 6.15 tons of GKP per hectare. However, in 2017, the harvest area was slightly decreased to 390 hectares, but the productivity increased significantly to 6.71 tons GKP per hectare.

Factors Affecting Rice Productivity in the Second Planting Season. A research sample covering 40 farmers were drawn from the population in the study area. The characteristics of respondents based on sex indicated that majority of respondents were male $(92.5 \%)$. The age of respondents was between the 37 years to 67 years, but majority of respondents were in the productive aged of 41-50 years. Majority of respondents own and cultivate rice in the average area of 1 hectare.

In order to assess the influence of factors affecting the productivity of rice in the second planting season, a multiple regression analysis was performed (Table 4). The independent variables assumed to affect the productivity of rice $(Y)$ in the second planting season as discussed above were farmers' technical ability in lowland rice cultivation $\left(X_{1}\right)$, production facilities and infrastructures $\left(X_{2}\right)$, and irrigation networks $\left(X_{3}\right)$.

Table 4 - Results of Multiple Regression Analysis

\begin{tabular}{lcccc}
\hline \multicolumn{1}{c}{ Variable } & Coefficient & Standard Error & $\mathrm{t}$ & Sig \\
\hline Constant & -.908 & .203 & -4.465 & .000 \\
Farmers' technical ability $\left(\mathrm{X}_{1}\right)$ & .087 & .006 & 13.391 & .000 \\
Production facilities and infrastructure $\left(\mathrm{X}_{2}\right)$ & .081 & .011 & 7.229 & .000 \\
Irrigation networks $\left(\mathrm{X}_{3}\right)$ & .103 & .020 & 5.047 & .000 \\
\hline \multicolumn{2}{c}{ Sig $\mathrm{F}=.000 ; \mathrm{R}$ square $=0.97$} & & & \\
\hline
\end{tabular}

Based on the above analysis, the regression equation of the productivity of lowland rice in the second planting season can be stated as

$$
Y=-0,908+0.087 X_{1}+0.081 X_{2}+0,103 X_{3}
$$


Where: $Y=$ Productivity of rice in the second planting season; $\alpha=$ Constant; $\beta=$ Regression coefficient; $X_{1}=$ Farmers' technical ability to perform rice cultivation; $X_{2}=$ Facilities and infrastructures (seeds, fertilizer, pesticides, machinery); $X_{3}=$ Irrigation networks.

Based on the analysis, the effect of all the independent variables were significant statistically. The influence of all the independent variables on the productivity of rice in the second planting season was positive, which mean that every individual independent variable had significant positive contribution to the dependent variable. Overall effect of the independent variables on the productivity of rice was also significant based on the value of $F$ test.

The individual effect of farmers' technical ability in rice cultivation on the productivity of rice in the second planting season is positive (as indicated by the coefficient) and significant (as indicated by the significance of t-test). This indicated that the higher the farmers' ability in rice cultivation the higher the productivity of rice in the second planting season.

The effect of facilities and infrastructures on the productivity of rice in the second planting season is also positive (as indicated by the coefficient) and significant (as indicated by the significance of t-test). This indicated that the better the facilities and infrastructures the higher the productivity of rice in the second planting season.

The influence of irrigation networks on the productivity of rice in the second planting season is also positive (as indicated by the coefficient) and significant (as indicated by the significance of t-test). This indicated that the better the irrigation networks that support rice cultivation the higher the productivity of rice in the second planting season. Water availability for rice cultivation was proved to be crucial for rice cultivation in the second planting season where water was less available.

\section{CONCLUSION}

Rice cultivation in lowland areas of Palembang in the second planting season has been implemented in several districts since 2015. However, the realization of planting and harvest area varied among locations. Overall, rice cultivation in the second planting season in Palembang was proved to be successful in term of the increase in harvest area and the productivity.

The productivity of lowland rice cultivated in the second planting season was influenced significantly by three factors considered in the study. The effect of farmers' technical abilities in lowland rice cultivation, production facilities and infrastructures, and irrigation networks were statistically significant on the productivity of rice in the three districts in Palembang.

This study proves that rice cultivation in lowland areas in the City of Palembang can support the achievement of rice production sufficiency. Therefore, the efforts to utilize the available lowland areas surround the city should be sustained.

\section{REFERENCES}

1. Agriculture and Food Security Agency of Palembang. 2017. The Potentials of Agriculture Sector in Palembang.

2. Agus, F., and Irawan. 2006. Agricultural land conversion as a threat to food security and environmental quality. Agriculture Research and Development Journal 25(3); 90-98.

3. Central Bureau of Statistic of Palembang. 2016. Palembang Municipality in Figures.

4. Directory General of Foods and Crop. 2013. Guidance for Increasing Production and Productivity of Irrigation and Swamp Rice to Support National Rice Production. Ministry of Agriculture of the Republic of Indonesia.

5. Sulaeman, D. 2005. Suitability of Land, Irrigation, and People Culture in Rice Cultivation. The Ministry of Agriculture of the Republic of Indonesia. 